O hodowli in vitro wycinków z łodygi rącznika (Ricinus communis L.) i wilczomlecza tyrlicza (Euphorbia lathyris L.)

\author{
B. WOJCIECHOWSKA, H. DAJNOWICZ-KOLBE, A. WORKOWSKA
}

Zakład Botaniki Instytutu Biologii Uniwersytetu Sląskiego, Katowice, ul. Jagiellońska 28

B. Wojciechowska, H. Dajnowicz-Kolbe, A. Workowska, Institute of Biology, Silesian University, Katowice, Jagiellońska 28, Poland (Received: June 15, 1970).

In vitro culture of segment from shoots of Ricinus communis $L$. and Euphorbia lathyris $L$.

Abstract:

The influence of certain factors on the growth and differentiation of the material investigated was analysed. Histo- and organogenesis are discussed together with the anatomy of the coalescence of the segments.

\title{
WSTEP
}

Bogata literatura z zakresu kultur in vitro omawia procesy rozwoju tkanek i organów oraz uwzględnia mechanizm ich zrastania się ze sobą. Wyniki badań przeprowadzonych przez C a m us a (1943-47), C a mus a i Gauthereta, Roppe (1948) cytował w krajowej literaturze między innymi R o d ki e w i c z (1952), który śledził procesy zachodzące przy zrastaniu się tkanek marchwi. Podczas analizowania czynników odpowiedzialych za indukowanie procesów histogenezy w zrastających się tkankach lilaka Wetmore i Sorokin (1955) zwrócili uwagę na możliwości zastąpienia substancji wytwarzanych przez rośliny w stożkach wzrostu pędu przez czynniki chemiczne. Stwierdzono, że działanie auksyn można regulować wprowadzając $\mathrm{w}$ odpowiednim stosunku adeninę-A, kinetynę-K oraz niektóre cukry (W e t mor e i S or okin 1955; H owell i Skoog 1955; Skoog i inni 1967; Rogozińska 1968; Torrej 1958).

Jednak okazało się, że niektóre czynniki chemiczne są mało specyficzne w działaniu, a hodowane tkanki reagują inaczej niż tkanki i kalusy testowe marchwi, tytoniu itd. (O ls z e w s k a i inni 1957). 
Na procesy wzrostu i rozwoju kalusa i wycinków regulujący wpływ wywierają również czynniki zewnętrzne ( $\mathrm{S}$ ła bę d z k a-S z w e y k o wska 1952; Ga jew ski 1954, R en ert 1965).

$\mathrm{W}$ dostępnym piśmiennictwie nie znaleziono danych o hodowli in vitro tkanek rącznika. W roku $1957 \mathrm{M}$ on ta n t przedstawił wyniki hodowli tkanek korzenia Euphorbia characiens na pożywce Knopa z dodatkiem IAA w stężeniu $1 \mathrm{mg} / \mathrm{l}$ pożywki, oraz tiaminy, mezoinozytu, kwasu nikotynowego i biotyny. Do pożywki dodano penicyliny. Było to konieczne ze względu na obecność endobakterii w tkankach wilczomlecza.

Punktem wyjściowym niniejszych badań były wyniki uzyskane podczas szczepienia wegetatywnego między rącznikem i wilczomleczem (W o j c i e c how s ka w druku).

Celem podjętej pracy było sprawdzenie zdolności regeneracyjnych uszkodzonych tkanek i porównanie wycinków hodowli in vitro z wynikami uzyskanymi uprzednio in vivo.

\section{CZĘSC DOSWIADCZALNA}

\section{Materiał i metody pracy}

Materiał do badań stanowiły łodygi Ricinus communis L. i Euphorbis lathyris L. W celach porównawczych użyto również łodygi E. marginata Pursh i E. platyphyllos L. Rośliny hodowano w wazonach. Nasiona otrzymano z Ogrodów Botanicznych w Bremie, w Halle, z Ogrodu Instytutu Roślin Leczniczych w Poznaniu i Ogrodu Farmakognozji A. M. w Łodzi.

Wycinki do hodowli in vitro pobierano $\mathrm{z}$ roślin rącznika tuż przed kwitnieniem. Przed zabiegiem, łodygi i ogonki liściowe sterylizowano zewnętrznie. Narzędzia i stół odkażano etanolem, a następnie naświetlano przez 30 minut lampą kwarcową. Łodygi skrawano żyletką. Z łodyg wilczomlecza odcinano części szczytowe, około $4 \mathrm{~cm}$ długie i gęsto ulistnione, usuwano stożek wzrostu pędu wraz z przylegającą strefą o długości równej około $0,8 \mathrm{~mm}$ i delikatnie oddzielono liście. Siewki rącznika użyto w stadium 4-7 liści. Wykorzystano odcinki o długości $1,5-2 \mathrm{~cm}$. Ogonki liściowe rozcinano wzdłuż na 4 części i poprzecznie co $0,5 \mathrm{~cm}$.

Fragmenty łodyg dzielono na krążki o wysokości $3-5 \mathrm{~mm}$. Następnie część przecinano wzdłuż średnicy na połowy lub ćwiartki. Epidermy nie usuwano. Na płytkach Petriego układano po 2, 3, 4, lub 6 eksplantatów, a do probówek ze skośnie zestaloną pożywką po 2 . W każdej serii wyszczepiano około 60 eksplantatów.

$\mathrm{W}$ pierwszej serii hodowano wycinki pobrane z łodygi jednego gatunku. Celem stwierdzenia, czy w hodowli in vitro dojdzie do zrośnięcia się tkanek wycinków pobranych z jednej łodygi wykonano doświadczenia $\mathrm{w}$ tym zakresie. Kontynuując badania nad histologiczną reakcją przyranną w miejscu połączenia się tkanek zraza i podkładki przeprowadzono 
hodowle wycinków rącznika, na które nałożono wycinki z łodygi wilczomlecza (rys. 1). Ṕonieważ w czasie badań in vivo zauważono, że wyniki doświadczenia zależą od stadium rozwojowego rośliny, hodowano również wycinki z części podliścieniowej młodych siewek rącznika.

Uwzględniono wpływ światła, temperatury, pory roku oraz niektórych składników pożywki (sole mineralne w różnym stężeniu, substancje wzrostowe, witaminy i wyciąg z drożdży). Stosowano pięć pożywek:

A - pożywka mineralna White'a z dodatkiem ekstraktu drożdżowego wg Ruge (1965),

B - czterokrotnie stężona pożywka mineralna White'a z dodatkiem ekstraktu drożdżowego wg R u g e (1955),

C - pożywka (B) zamiast wyciągu z drożdży uzupełniona mikroelementami, witaminami i substancjami wzrostowymi (adenina$-40 \mathrm{mg}$ i kwas indolilooctowy-IAA 2,0 mg na litr pożywki),

$\mathrm{D}$ - skład jak w pożywce $\mathrm{C}$ z dodatkiem $1 \mathrm{mg}$ kinetyny-K,

E - skład jak w pożywce D (adenina w ilości $20 \mathrm{mg}$ ).

Pożywki uzyskano z Katedry Fizjologii Roślin U.モ.

Temperaturę po pierwszych doświadczeniach regulowano w granicach $28-30^{\circ} \mathrm{C}$ w latach 1962 i 1963 , oraz $32-34^{\circ} \mathrm{C}$ w latach $1963-1965$. Kultury obserwowano w ciągu 2 miesięcy.

W okresie od maja do września uzyskiwano z reguły kultury sterylne, w pozostałych miesiącach procent zainfekowanych eksplantatów wynosił mniej niż 30 .

Przy wyborze materiałów do badań anatomicznych kierowano się makroskopowo widocznymi zmianami w strukturze i rozmiarach eksplantatów. Materiały konserwowano w mieszaninie alkoholu, gliceryny i wody (1: $1: 1)$. Skrawki o grubości $15-20 \mu$ przygotowano przy pomocy mikrotomu zamrażającego, a część przy pomocy żyletki. Wykonano preparaty trwałe. Niektóre przechowywano bezpośrednio w odczynnikach na tłuszcze, drzewnik, celulozę, pektyny. Odczynniki przygotowano wg powszechnie znanych przepisów (L a n geron 1949, Filutowicz, Kużdow i c z 1951). Ilustracje wykonano przy pomocy aparatu rysunkowego.

\section{OMOWIENIE WYNIKOW DOSWIADCZEŃ}

Na pożywce mineralnej White’a wzrost wycinków był nikły i łącznie z cienką warstewką kalusa nie przekraczał $20 \%$ pierwotnej objętości.

$\mathrm{U}$ wilczomleczy rozwijaly się nieliczne włoski przyranne.

$\mathrm{Na}$ eksplantatach z łodygi rącznika dochodziło w tych warunkach do rozrastania się niektórych komórek kory pierwotnej i powiększania się lub rozrywania komórek skórki. Zgodnie ze znaną małą aktywnością merystematyczną skórki, sporadycznie wystąpiły w niej podziały.

Po znacznym powiększeniu się rozmiarów odróżnicowanych komórek miękiszu kory pierwotnej lub kolenchymy, zakładały się ściany dzielące 
komórkę macierzystą w kilku płaszczyznach. Prowadziło to do nierównomiernego rozrastania się wycinków i tworzenia pseudopączków (rys. 2). Również i na wycinkach pobranych z ogonków liściowych rącznika wystąpiły podobne procesy, ale podziały były mniej liczne, a pseudopączki małe.

Podczas dzielenia łodyg na segmenty, uszkadzano część komórek, które uległy nekrozie. Ich plazmatyczna treść zestalała się, łączyła w drobne i grubsze ziarnistości, a ściany stopniowo się rozpuszczały.

$\mathrm{Na}$ pożywce B bujniej rozwijały się wycinki rącznika. Najpierw pojawił się niepozorny białawy i szybko żółciejący puszysty kalus. Po kilku dniach wycinki rącznika rozrastały się nieregularnie, a kalus tworzył szkliste płaty i brodawki (fot. 1). U wilczomleczy tkanka kalusowa rozwijała się znacznie słabiej niż u rącznika w postaci równomiernie rozwiniętego, biało zielonego pierścienia. $\mathrm{Na}$ obwodzie był on zawsze puszysty i matowy (fot. 2). Stąd od pierwszych dni hodowli makroskopowo można było zauważyć różnice w ukształtowaniu tkanek na wolnej powierzchni wycinków.

W stronę pożywki kalus narastał zawsze intensywniej jako prawie bezbarwna lub kremowa tkanka obficiej u rącznika niż u 3 badanych gatunków wilczomleczy.

Optimum rozwoju eksplantatów najczęściej przypadało na 3 i 4 tydzień hodowli. Później tkanki brunatniały i przeniesione na nowe podłoże nie przejawiały tendencji do dalszego rozwoju. Podobnie zachowywał się kalus ścięty z górnej powierzchni eksplantatów.

$\mathrm{Na}$ pożywce C zawierającej IAA w ilości $2 \mathrm{mg} / \mathrm{l}$ i A w ilości $40 \mathrm{mg} / \mathrm{l}$ znacznie powiększała się objętość wycinków i obficiej niż na pożywce B narastał kalus. Z reguły 3 lub 4 wycinki rosły szczególnie aktywnie. Tak

Fot. 1. Pierwsze stadium rozwoju kalusa na dopowietrzonej stronie wycinka łodygi rącznika

First stage of callus development on the aerial side of the Ricinus shoot segment

Fot. 2. Pierwsze stadium rozwoju kalusa na dopowietrznej stronie wycinka z łodygi wilczomlecza tyrlicza

First stage of callus development in the aerial side of the Euphorbia shoot segment

Fot. 3. Liść rozwijający się na wycinku z lodygi rącznika

A developing leaf from Ricinus shoot segment

Fot. 4. Korzeń wyrastający z wycinka wilczomlecza tyrlicza

A developing root from Euphorbia shoot segment

Fot. 5. Warstwa kalusa między wycinkami rącznika i wilczomlecza A callus layer between the Euphorbia and Ricinus segments

Fot. 6. Strefa zrostu między tkankami rącznika i wilczomlecza

A growth zone between the tissues from Ricinus and Euphorbia 

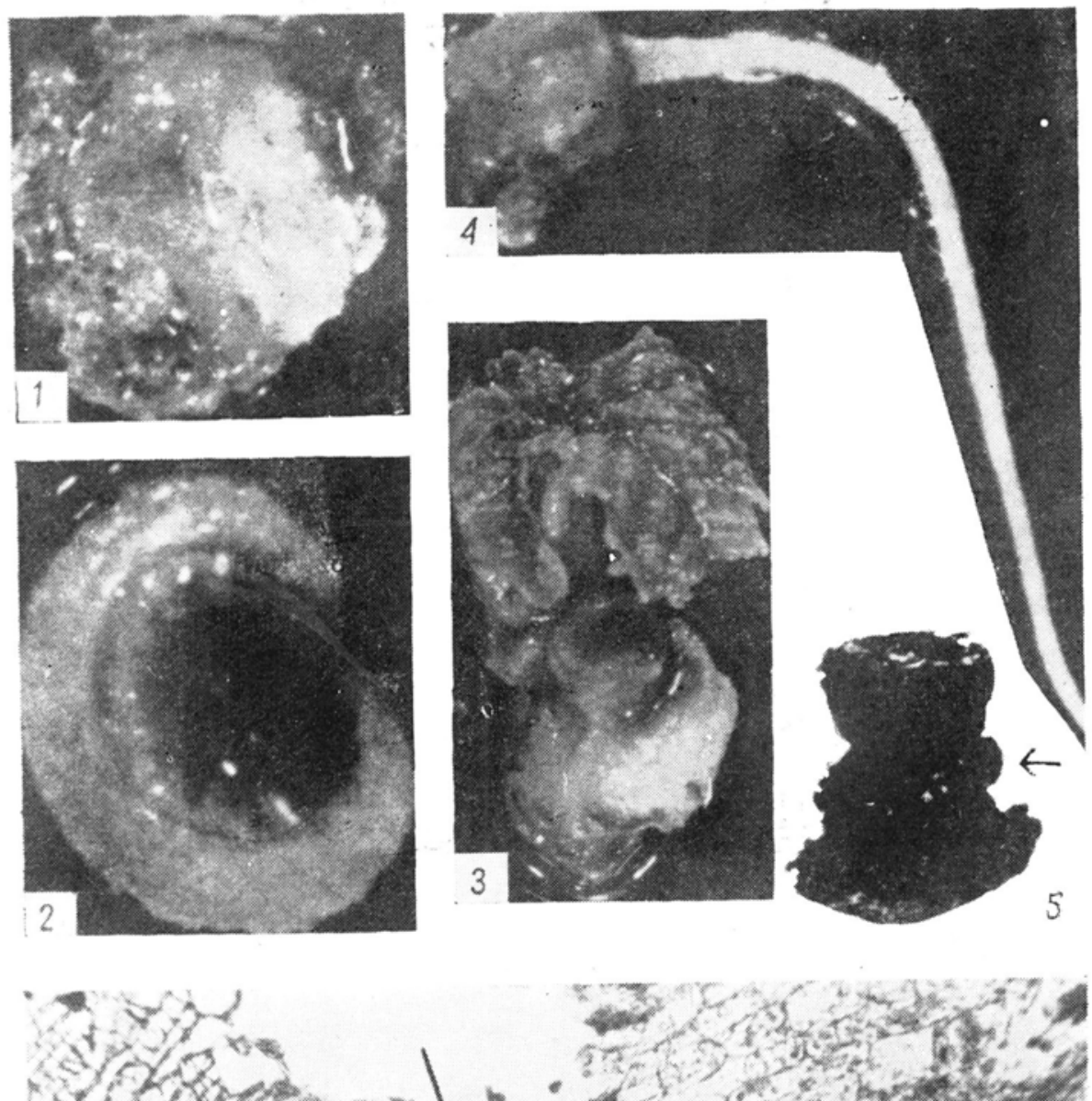



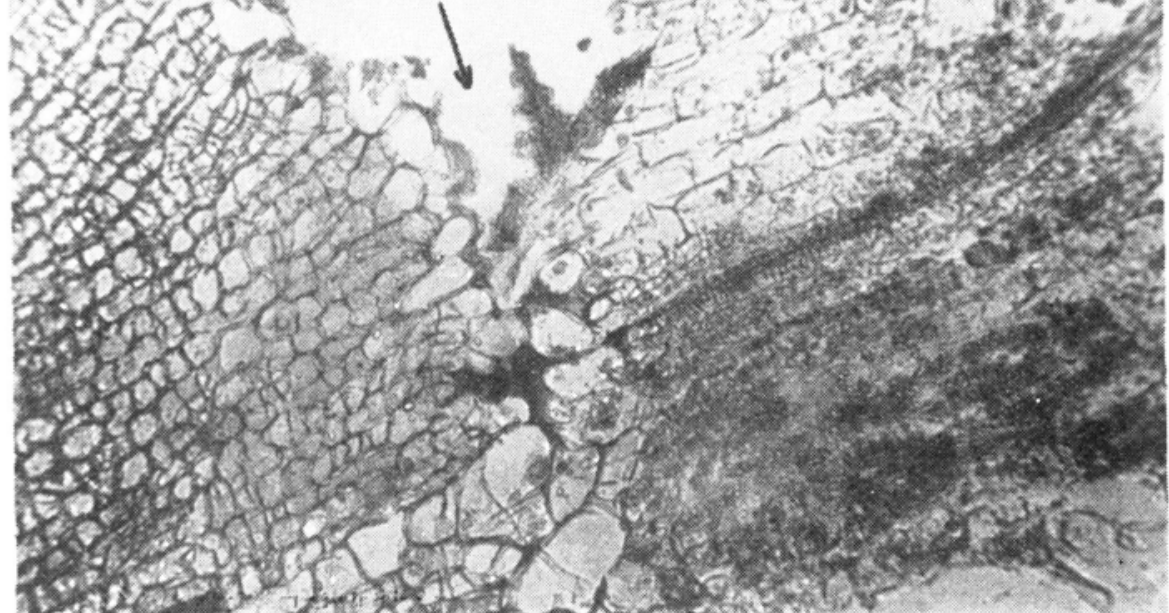


u rącznika, jak wilczomlecza tyrlicza rozwinęły się korzenie. Optimum rozwoju eksplantatów przypadało na $18-24$ dzień. Pierwsze punkty nekrotyczne wystąpiły w piątym tygodniu hodowli. Temperatura wynosiła $28^{\circ} \mathrm{C}$ i w powtórzeniu doświadczenia $30^{\circ} \mathrm{C}$.

Celem następnych doświadczeń były próby sprawdzenia wpływu kinetyny $(\mathrm{K})$ wobec IAA i A zawartych w pożywce w stężeniu jak wyżej. Kinetynę dodano w ilości $1 \mathrm{mg} / \mathrm{l}$. Temperatura była regulowana w granicach $28-30^{\circ} \mathrm{C}$ i $32-34^{\circ} \mathrm{C}$. Dni były słoneczne. Na pożywce (D) po czterech tygodniach hodowli uzyskano silny rozwój wycinków rącznika, które wyglądały jak nieforemne bryłki. Wcześniej niż na innych pożywkach wyróżnicowały się pączki i rozwijały liście. Blaszki liści osiągnęły około 2,5 cm średnicy (fot. 3). U rącznika później i rzadziej niż u wilczomlecza tyrlicza powstawały korzenie. Rosły one wolno i nie przekraczały $1,5 \mathrm{~cm}$ dł. W tych warunkach u Euphorbia lathyris nie dochodziło do wytwarzania pączków, silnie natomiast rozwijały się korzenie. $\mathrm{Z}$ reguły jednej z nich wyrastał szybciej (fot. 4) i przy $3,5 \mathrm{~cm}$ posiadał już kilka korzeni bocznych. Długość niektórych dochodziła do $16 \mathrm{~cm}$.

Rys. 1. Zrastające się ze sobą wycinki rącznika i wilczomlecza Concrescence of segments from Ricinus and Euphorbia

Rys. 2. Pseudopączki u rącznika Buds from Ricinus

Rys. 3. Wycinek z lodygi rącznika $a$ - wzrost elongacyjny komórek perycyklu; $b$ - warstwa merystematyczna; $c$ włókna pochodzenia perycyklicznego

Segment from Ricinus shoot $a$ - elongative growth of pericycle cells; $b$ - meristematic layer; $c$ - the fibers orginating from pericycle

Rys. 4. Schemat wycinka z lodygi rącznika

$a$ - warstwa merystematyczna; $b$ - warstwa merystematyczna w odróżnicowanym drewnie (c); $d$ - rdzeń; $e-$ nowy ośrodek merystematyczny w zewnętrznej części kalusa

A scheme of a segment from Ricinus shoot

$a$ - meristematic layer; $b$ - meristematic layer from dedifferentiated wood (c); $d-$ pith; $e-$ new meristematic centre in external part of the callus

Rys. 5. Warstwa merystematyczna (a). Preparat w czerwieni rutenowej. Komórki zabarwione zakropkowano

Meristematic layer $(a)$. Ruthenium red preparation. The stained cells are shaded

Rys. 6. Wycinek łodygi rącznika (a) z przyrośniętym wycinkiem wilczomlecza tyrlicza (b), c - rozwijający się pączek boczny

(Zaznaczono lokalizację cewek i kryształów szczawianu wapnia (x))

A segment of Ricinus shoot (a) with concrescensed Euphorbia segment (b), $c$ - developing lateral bud

(The localization of tracheids and of calcium oxalate cristals is marked $(x)$ )

Rys. 7. Linia graniczna między zrastającymi się tkankami rącznika i wilczomlecza The border line between the coalescence of Ricinus and Euphorbia tissues 
Zmniejszenie stężenia A z 40 do $20 \mathrm{mg} / 1$ (pożywka E) zahamowało rozwój kalusa, szczególnie na słabiej rosnących wycinkach wilczomleczy, a indukowało ryzogenezę na wycinkach rącznika. Liczne związki korzonków były ustawione w jednym okółku na stronie dopowietrznej.

$\mathrm{Na}$ pożywce C, D i E w pierwszym rzędzie odróżnicowaniu i silnemu rozrostowi podlegały komórki kory pierwotnej oraz nieco później perycyklu i rdzenia. Wzrostem elongacyjnym były objęte ściany promieniowe komórek. Stopniowe rozciągania się komórek wzdłuż promieni powodowało wielokrotne zwiększenie objętości eksplantatów. Jednocześnie na powierzchniach obydwu wycinków - dopowietrznej i dopożywkowej - roz-

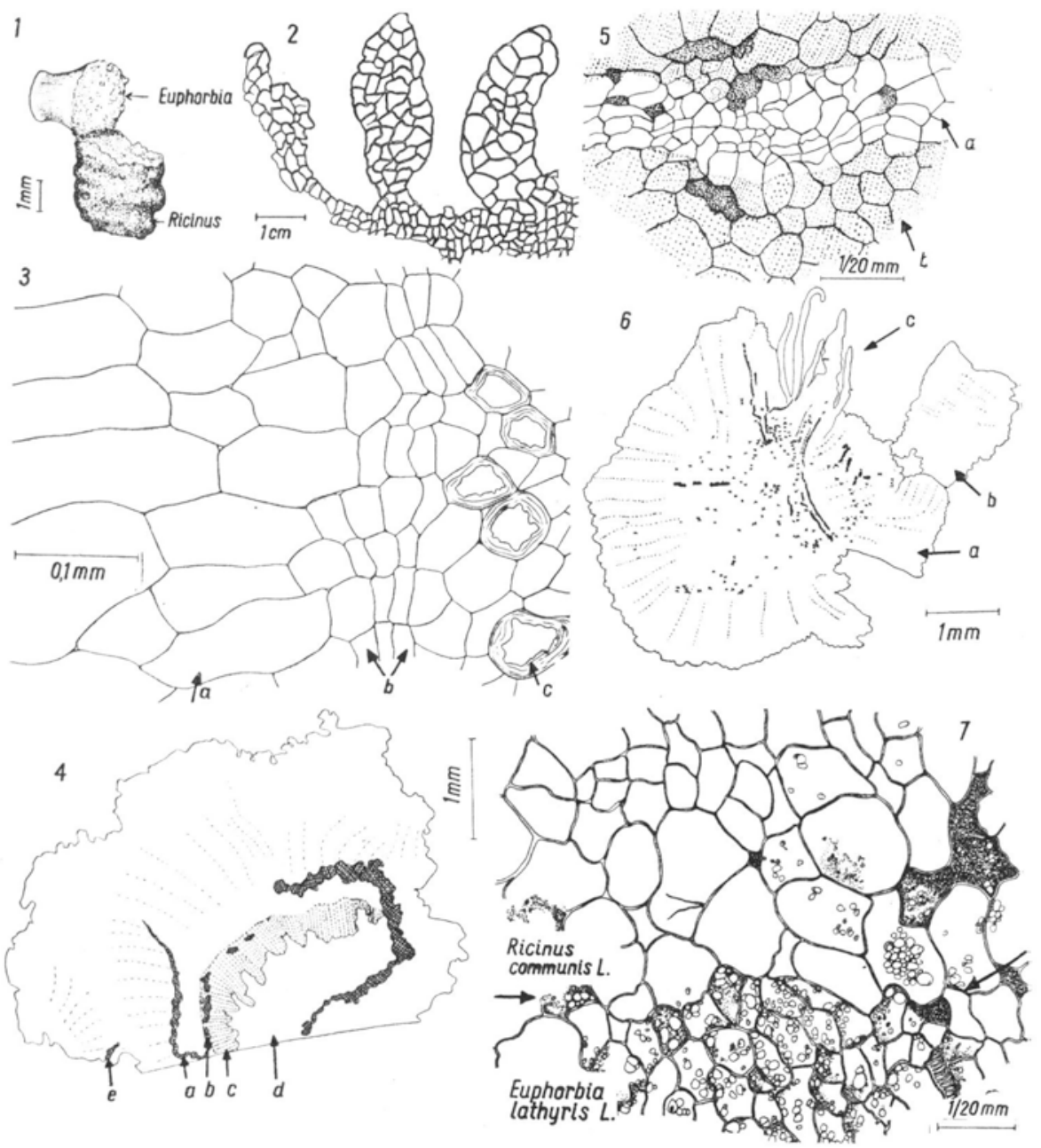


wijała się warstewka kalusa. Część silnie wydłużonych komórek zmieniała kierunek wzrostu i odchylała się ku powierzchni dolnej lub górnej eksplantatów. Szczytowe części tych komórek rozdymały się buławkowato mieszcząc w sobie dużą wodniczkę i jedną lub dwie grupy plastydów. Blisko części szczytowej leżało również duże jądro. Na ryc. 3 wskazano kilka komórek perycyklu w początkowym stadium wydłużania (rys. 3a). Przylegają one do warstwy merystematycznej (rys. 3b). Podlegające odróżnicowaniu włókna perycykliczne można zlokalizować biorąc pod uwagę szerokość ściany komórkowej (rys. 3c).

Kalus produkowany przez koronę rdzeniową składał się z komórek o wyraźnie mniejszych wymiarach, które zawierały drobne plastydy. $\mathrm{Na}$ wycinkach z łodygi rącznika hodowanych przez 5 tygodni na pożywce D następowało formowanie się wtórnych ognisk merystematycznych. Zgodnie ze spostrzeżeniami R odkie wi c z a (1952) oraz We tmore i S or o kin a (1955) pierwszy szereg komórek inicjalnych zakładał się u podstawy kalusa i tworzył łuk. Łuk ten przebiegał mniej wiecej równolegle do linii perycyklu, zaginał się u brzegów wycinka, mijał miazgę i półkoliście przecinał rdzeń. Następne gniazda merystematyczne powstawały w obwodowych częściach kalusa. Miało to miejsce wtedy, kiedy na wycinku rącznika hodowano wycinek wilczomlecza. Warstwy komórek inicjalnych przedstawiono na schematyzowanym rysunku 4 oraz w dużym powiększeniu na rys. 3 i 5. Równocześnie dochodziło do zakładania wtórnych drobnych gniazd merystemów w drewnie. Początkowo miazga nie brała jeszcze udziału w procesach regeneracyjnych $\mathrm{w}$ takim stopniu, aby to można stwierdzić histologicznie. W późniejszym okresie, w wyniku dziłania miazgi zostały odłożone szeregi drobnych, niezróżnicowanych komórek w stronę łyka. Przyrost w stronę drewna od razu różnicował się w cewki, naczynia i miękisz przewodzący.

$\mathrm{Na}$ wycinkach rącznika hodowanych na pożywce D szybko rozwijały się pączki otulone liśćmi (rys. 6). Do ich podstawy dochodziły sznury wiązek przewodzących oraz rozrzucone w miękiszu zgrupowania cewek. Błony cewek miały z reguły siateczkowate zgrubienia. W sąsiedztwie intensywnie dzielących się i rosnących komórek, tuż pod wykształconym pączkiem bocznym oraz blisko części naczyniowej wiązek znajdują się liczne druzy szczewianu wapnia. Podobną lokalizację stwierdzono w tkankach rącznika po szczepieniu wegetatywnym, gdzie „bariery szczawianowe” stanowiły granicę między tkankami starymi a przechodzącymi od stadium podziałów do różnicowania się (W o j c i e chow ska w druku). Nie są to jedyne obserwacje $\mathrm{z}$ tego zakresu, a masowe występowanie kryształów szczawianu wapnia było już w literaturze dyskutowane.

Analiza stosunków w badanym obecnie materiale zdaje się wskazywać, że pojawienie się tych kryształów jest skorelowane z przemianami w chemiźmie ścian komórkowych, a ściślej z ich inkrustacją substancjami wykrywanymi przy pomocy floroglucyny i $48 \% \mathrm{H}_{2} \mathrm{SO}_{4}$. 
Reakcje histochemiczne przeprowadzone w celu poznania składu ścian komórkowych wykazały bardzo interesujące zjawisko. W wyniku reakcji na drzewnik (floroglucyna z 48\% kwasem siarkowym), uzyskano jasne, czerwonomalinowe zabarwienie komórek merystematycznych. Podobnie były zabarwione młode naczynia metaksylemu. Elementy protoksylemu, część komórek kalusa i niektóre komórki wycinków, np. odróżnicowujące się komórki zwarcicy albo komórki uszkodzone w czasie skrawania, były czerwonobrunatne. Takie zabarwienie jest związane z obecnością domieszek (tłuszcze, pektyny, substancje gumowate). Jak zauważono na starszych eksplantatach drzewnik występuje też w komórkach kalusa przylegających do warstwy merystematycznej, oraz wszędzie tam, gdzie komórki wchodzą w stadium podziałów i różnicowania w elementy przewodzące (cewki i naczynia). Obecność drzewnika u podstawy luźno strukturalnego kalusa jest uzasadniona. Z badań Rodki ewicza (1952) wynika, że drzewnik występował na wycinkach z korzenia marchwi w komórkach grubościennych zlokalizowanych na granicy między starymi i nowowytworzonymi tkankami. W rejonie działalności kambium warstwa komórek grubościennych znikała. Nie wiadomo jednak, jakie były wyniki reakcji na drzewnik w komórkach inicjalnych.

Lokalizacja związków pektynowych wykazała, że w największych ilościach można je wykryć w ścianach niektórych komórek kalusa. Stanowią bowiem główny składnik ściany w okresie wzrostu elongacyjnego. Natomiast warstwa komórek inicjalnych prawie nie zawiera związków pektynowych.

Ze względu na nietypowe wybarwienie treści komórek inicjalnych oraz minimalną grubość ścian komórkowych, warstwa merystematyczna zostaje jeszcze bardziej wyeksponowana $\mathrm{z}$ otaczającego ją tła. Np. w czerwieni rutenowej ściany komórek wycinków i kalusa są zabarwione intensywnie cyklamenowo, podczas gdy ściany komórek dzielących się są słabo różowe. Odłożone bezpośrednio po cytoklinezie w ogóle nie zostają zabarwione, a treść komórkowa jest żółta (rys. 5a). Stąd należy przypuszczać, że w bardzo młodych ścianach brak substancji pektynowych, które pojawiają się po zakończeniu pewnej fazy podziału albo wyżej wymieniony odczynnik reaguje tylko z niektórymi substancjami pektynowymi.

W odczynnikach na tłuszcze zawsze intensywniej wybarwiają się tkanki wilczomlecza tyrlicza niż tkanki rącznika. U rącznika, jasny, różowoczerwony kolor w roztworze Sudanu III i IV mają ściany wszystkich komórek merystematycznych, tak położonych w głębi wycinków, jak i na obwodzie kalusa. Wyraźnie słabiej reagują ściany komórek miazgi.

Regeneracja histologiczna na wycinkach wilczomleczy w hodowli in vitro miała przebieg bardzo podobny jak we wspomnianych badaniach in vivo. Z reguły na uszkodzonej powierzchni rozwijały się w kilku warstwach komórki tkanki o charakterze przejściowym między korkiem przyrannym a tkanką pośrednią. Komórki były drobne, ustawione w promie- 
niste szeregi, raczej grubościenne i bardzo intensywnie reagowały z odczynikami na tłuszcze. W ścianach wystąpiły nieznaczne domieszki drzewnika. Najsilniej barwiła się warstwa podstawowa, granicząca z tkankami wycinka. Równocześnie z rozwojem tkanki powierzchniowej rozrastały się komórki zlokalizowane w głębi eksplantatów. Reakcją zostawał objęty wycinek o szerokości wyznaczonej przez tkankę rozrastającą się na uszkodzonej powierzchni. Z perycyklu wyrastały w tym miejscu zawiązki korzeni zbudowane $\mathrm{z}$ drobnych komórek wypełnionych plazmą. Tworzyly one ciemne smugi przecinające korę pierwotną. U ich podstawy rozrastało się łyko, miazga i drewno. Miazga tworzyła linię falistą, a elementy drewna często zmieniały kierunek wzrostu. Powstawały cewki poprzeczne. Komórki rdzenia nieco się rozrastały. Różnicowały się w tkankę pośrednią między kalusem a korkiem przyrannym (jeżeli były uszkodzone) albo przeróżnicowały się w krótkie cewki. W przypadku masowego przeróżnicowywania komórek powstawał słup elementów przewodzących prawie całkowicie wypełniający rdzeń.

Jeżeli wycinek z łodygi wilczomlecza tyrlicza położono nie na podłożu agarowym, a na wycinku z łodygi rącznika, wtedy między różnogatunkowymi tkankami wytwarzały się komórki zrostowego kalusa (rys. 7 i fot. 6). Na linii granicznej znajdowała się bardzo wąska warstewka ziarnistej substancji zabarwionej zielono-biało, oraz resztki ścian komórkowych. Na rys. 7 i fot. 6 granicę między obcogatunkowymi wycinkami wskazano przy pomocy strzałek.

Komórki tkanki pośredniej wytworzonej przez rącznik są większe i prawie puste optycznie. Ściany są cienkie i słabo się barwią w roztworze Sudanu III. Komórki o największych rozmiarach stykają się bezpośrednio z komórkami wycinka wilczomlecza. Te ostatnie z reguły są drobne i wypełnione ziarnami skrobi, kroplami łtuszczu i ziarnistą cytoplazmą. Wszystkie komórki wycinka wilczomlecza, łącznie z naczyniami intensywnie się barwią w roztworze Sudanu I lub IV. Ich charakterystyczną cechę stanowi bardzo mała tendencja do podziałów i znaczna łatwość od odróżnicowania się i bezpośredniego łączenia się z obco gatunkowymi tkankami. Na rys. 7 można zobaczyć zaledwie kilka komórek kalusa wytworzonych przez tkanki wilczomlecza. Są one zlokalizowane przy strzałkach.

$\mathrm{Na}$ linii granicznej między różnogatunkowymi tkankami brak komórek korka przyrannego, a więc tkanki zrosły się ze sobą.

Jako kryterium pełnego zrostu między dwoma wycinkami przyjmuje się nie tylko połączenie przez kalus, ale również wytworzenie połączenia między tkankami przewodzącymi obydwu wycinków. Stanowisko takie winno być przedyskutowane ponieważ różnicowanie się komórek jest kolejnym etapem reakcji regeneracyjnej i zależy od bardzo wielu czynników. Główną rolę w indukowaniu tkanki przewodzącej odgrywają substancje wzrostowe, składniki mineralne oraz cukrowce. Ważny jest kierunek wnikania substancji i jej stężenie. Na różnicowanie tkanki naczy- 
niowej wywierają pewien wpływ nieznane substancje produkowane przez pączek albo obecność tkanki przewodzącej w jednym $\mathrm{z}$ eksplantatów (rys. 1).

Przy rozpatrywaniu możliwości i sposobów zrastania się wycinków uderzał brak wymagań w stosunku do składników pożywki. Na pożywkach B-E wycinki rącznika i wilczomlecza zrastały się ze sobą po 12 do 16 dniach. Kalus rozwijał się intensywnie i prędzej niż na wycinkach hodowanych osobno. Procesy rozwoju i zrastania się przebiegały wolniej w przypadku łączenia dwóch wycinków z łodygi rącznika. Na żadnej pożywce nie stwierdzono zrostu między wycinkami z łodygi wilczomlecza.

\section{DYSKUSJA}

Na podstawie przeprowadzonych badań należy przypuszczać, że znaczne zdolności regeneracyjne rącznika ujawniają się dopiero w późniejszych stadiach rozwoju rośliny. Wycinki pobrane $\mathrm{z}$ roślin, które rozwinęły pierwsze międzywęźla rosły słabo i wytworzyły cienką warstewkę kalusa. Rośliny szczepione wegetatywnie również zrastały się dopiero po osiągnięciu fazy kwitnienia. Podobne rezultaty $\mathrm{w}$ badaniach in vivo uzyskał $\mathrm{K}$ u ż d ow i c z (1954) i M i c hni e wi c z (1956) szczepiąc rośliny z rodziny Solanaceae.

Analizując wpływ niektórych czynników zewnętrznych na rozwój wycinków zauważono zależność od cyklu rocznego. Aktywny rozwój był związany z miesiącami ciepłymi i słonecznymi (koniec kwietnia do końca sierpnia). Później procesy wzrostowe i morfogenetyczne ulegały zahamowaniu. Po wyraźnym, pierwszym etapie rozplemu, na wycinkach pojawiały się punkty nekrotyczne. Tkanki brunatniały i przeniesione na nowe podłoże zamierały.

Czas aktywnego rozwoju wycinków nie przekraczał pięciu tygodni. W miesiącach od stycznia do kwietnia, przyrost kalusa był nieznaczny, a na wycinkach pojawiały się mikroorganizmy częściej niż w innej porze roku. O istnieniu związku między rozwojem wycinków lub kalusów a cyklem rocznym istnieją liczne dane w piśmiennictwie.

Wyniki hodowli w znacznym stopniu zależały też od nasłonecznienia i temperatury, w której wykonywano doświadczenia, i nie zawsze były one porównywalne pod względem przyrostu masy kalusa. Najlepsze wyniki uzyskano przy $30-33^{\circ} \mathrm{C}$. Podniesienie temperatury do $34^{\circ} \mathrm{C}$ nie wpłynęło jednak w sposób widoczny na rozwój wycinków. Stąd wydaje się, że $34^{\circ} \mathrm{C}$ nie stanowi jeszcze górnej granicy rozwoju dla tych tkanek, ponieważ na obwodzie kalusa nie dochodziło do odkładania skorkowaciałych i drobnych komórek, których pojawienie przyjmuje się jako objaw starzenia się hodowli.

Bardzo różnie kształtują się też wymagania odnośnie do rodzaju i natężenia światła. 
Dla rozwoju tkanek z łodygi rącznika i wilczomleczy potrzebne jest światło dosyć silne i rozproszone. W tygodniach pochmurnych rozwój hodowli był wyraźnie zahamowany.

Rozpatrując wpływ podłoża stwierdzono, że 4-krotnie stężona pożywka mineralna White'a, zawierająca wyciąg z drożdży, okazała się mało przydatna do hodowli wycinków rącznika i wilczomleczy w produkcji kalusa. Natomiast proces zrastania się tkanek przebiegał na niej stosunkowo prędko. Najprędzej zrastały się ze sobą wycinki pobrane z łodygi Euphorbia i Ricinus, co wskazuje na wyraźną wzajemną tolerancję immunologiczną. Odpowiedzialny za stymulowanie reakcji zrostowych może się okazać dwuester forbolu. Jest to związek o działaniu kokarcinogennym wykryty u E. lathyris przez H e c k e r a (1968).

Na pożywkach White'a uzupełnianych substancjami wzrostowymi uzyskano makroskopowo widoczne minimum czterokrotne powiększanie objętości wycinków i znaczny przyrost kalusa. Kalus narastał na obydwu stronach wycinków, przy czym przyrost w stronę pożywki był większy i morfologicznie mniej zróżnicowany. Gaje wski (1954) tłumaczy to biegunowością i polarnym transportem substancji wzrostowych.

$\mathrm{Na}$ stosowanych pożywkach nie uzyskano jednak kalusa zdolnego od trwałego i nieograniczonego wzrostu. Przyczyny takiego stanu rzeczy mogły być związane z przeszczepieniem na nowe podłoże zbyt małych wycinków, pobranych tylko ze strony dopowietrznej. Być może kalus ścinano w nieodpowiednim okresie i za bardzo powierzchownie. Negatywne wyniki przy transplantacji kalusa mogą także wynikać z dziedzicznych właściwości badanych tkanek. Natomiast wydaje się, że efekty organogenetyczne były w głównej mierze regulowane stężeniem IAA, K i A. W obecności IAA(2 $\mathrm{mg} / 1 \mathrm{l})$ i $\mathrm{A}(40 \mathrm{mg} / 11$ pożywki), na wycinkach rącznika i wilczomleczy rozwijały się korzenie. Wprowadzeniem kinetyny w ilości $1 \mathrm{mg} / 1 \mathrm{l}$ pożywki wywołano tylko u rącznika zahamowanie ryzogenezy i indukowanie rozwoju pączków i pseudopączków.

Zmniejszenie ilości adeniny do $20 \mathrm{mg} / 1 \mathrm{l}$ pożywki spowodowało zahamowanie rozwoju pączków, a stymulację ryzogenezy u rącznika. Wycinki wilczomlecza nie reagowały na zmianę stężenia tej zasady purynowej.

Uzyskane wyniki wskazują, że tylko tkanki rącznika reagują podobnie jak tkanki tytoniu (S k o o g 1950, 1955 cyt. za O ls ze w ską i innymi (1957) i R o g o zińską (1961), dając dodatkowy atut tym, którzy uważają, że rozwój liści i korzeni wynika z synergicznego działania adeniny, kinetyny i kwasu indolooctowego dodanych do pożywki w określonym stosunku.

Z histologicznego punktu widzenia można uważać, że IAA dodany do mineralnej pożywki White’a w pierwszym rzędzie stymulował wzrost elongacyjny miękiszu u rącznika. Jednak tkanka miękiszowa z łodygi wilczomlecza nie wykazała takiej reakcji w wyżej omówionych warunkach. Należy też przypuszczać, że rozwój warstwy merystematycznej 
w kalusie był indukowany tak obecnością IAA, jak i K, ponieważ tak rola auksyn, jak i kinetyny polega na stymulowaniu podziałów komórkowych (Skoog i Miller 1957 oraz O ls z e w s k a inni 1957).

Ogólnie panuje pogląd, że bardzo młode ściany komórkowe są zbudowane z protopektyn i hemicelulozy, później także zawierają celulozę.

Wykonane obecnie reakcje histochemiczne wykazały, że w początkowych stadiach rozwoju ściany komórkowej, można w niej wykryć obecność substancji, które silnie reagują z floroglucyną i $48 \% \quad \mathrm{H}_{2} \mathrm{SO}_{4}$ oraz z Sudanem III lub IV. W tych odczynnikach barwią się wszystkie komórki merystematyczne. W okresie wzrostu elongacyjnego ściany zawierają nieznaczne ilości substancji tłuszczowych, są pozbawione związków reagujących z floroglucyną i $48 \% \quad \mathrm{H}_{2} \mathrm{SO}_{4}$, a ich głównym składnikiem są związki pektynowe. Sciany starszych komórek kalusa posiadają już złożony skład chemiczny, stąd wyniki reakcji lsarwnych są mniej czyste. Szczawian wapnia w postaci krystalicznej najprawdopodobniej zostaje odłożony w czasie różnicowania komórek w elementy przewodzące, a więc podczas odkładania ligniny. Tak można tłumaczyć obecność tych kryształów w komórkach otaczających zgrupowania cewek i naczyń.

\section{STRESZCZENIE}

Przeprowadzono badania in vitro nad wzrostem, organogenezą i anatomią zrostu wycinków pobranych z lodygi rącznika i wilczomlecza tyrlicza.

Badano aktywność działania kwasu indolooctowego (IAA), kinetyny (K) i adeniny (A) dodanych do czterokrotnie stężonej pożywki mineralnej White'a. Zauważono, że działanie IAA i K można korelować zmieniając stężenie A.

Stwierdzono, że przyrost masy kalusa zależy w większym stopniu niż organogeneza od takich czynników, jak: temperatura, nasłonecznienie i pora roku. Ani skład pożywki, ani wspomniane wyżej czynniki zewnętrzne nie wywierają większego wpływu na proces zrastania się różnogatunkowych wycinków. Obydwa gatunki charakteryzuje znaczna tolerancja immunologiczna na soki ustrojowe partnera doświadczenia. Wydaje się, że obecność tkanek wilczomleczy wplywa stymulująco na procesy zrostowe i rozwój kalusa u rącznika.

Nie zauważono wyraźnych różnic histologicznych w przypadku hodowli roślin in vitro i in vivo.

Jednak wyraźny efekt elongacyjny komórek miękiszu kory pierwotnej, perycyklu i rdzenia u rącznika należałoby prawdopodobnie przypisać działaniu IAA. Natomiast efekty organogenetyczne (rozwijanie się korzeni i pączków) prawdopodobnie byly regulowane przez IAA, $\mathrm{K}$ i $\mathrm{A}$.

Część doświadczalną pracy wykonano w Zakładzie Botaniki Farmaceutycznej AM w Lodzi.

Panu Doc. dr hab. F. Celińskiemu autorzy dziękują za przejrzenie maszynopisu.

(Wpłynęło dn. 15. VI. 1970 r.) 


\section{SUMMARY}

Investigations were performed in vitro on the growth, organogenesis and anatomy of concrescence of segments taken from shoots of Ricinus communis L. and Euphorbia lathyris L.

The effect of indolylacetic acid (IAA), kinetin $(\mathrm{K})$, and adenine (A) added to a fourfould concentration of White's mineral medium was tested. It was found that the action of IAA and K may be correlated by changing the concentration of A. It was demonstrated that the increment in callus mass depends more than does organogenesis on such factors as temperature, insolation and season. Neither the compostion of the medium, nor the above named external factors exert a major influence on the concrescence of heterogenous segments. Both the species studied are characterised by a high immunological tolerance to the sap of the partner in the experiment. It would seem that the presence of the Euphorbia tissue has a stimulating influence on the process of coalescence and the development of callus in Ricinus.

No distinct histological differences were noted in the case of culture of the plants in vitro and in vivo. However, the marked effect of parenchyma cells elongation in the primary cortex, the pericycle and pith in Ricinus should may probably be attributed to the action of IAA. The organogenetic effect (development of roots and buds) were probably controlled by IAA, $\mathrm{K}$ and $\mathrm{A}$.

The experimental part of the study was performed in the Department of Pharmaceutical Botany, School of Medicine, Lódź.

The authors are indebted to $\mathrm{dr}$ hab. F. Celin s ki for critical reading of the manuscript.

\section{- Literatura}

B o 11 W., 1956, Effect of sucrose concentration leught of passage minor element nutrition, and $\mathrm{pH}$ value an growth of excised tomato roots, Bot. Gaz. 116, 2: $156-162$.

Camus G., 1949, Recherches sur le rok des bourgeons dans les phenomenes de morphogenesa, Rev. Cytol. Biol. Veg. 11: 1-195.

Filut owicz A., K użdowicz A., 1951, Mikrotechnika roślinna, PWR i L, Warszawa.

Ga je wski W., 1954, Zjawiska regeneracji u roślin. Zagadnienia regeneracji, Zeszyty problemowe „Nauki polskiej” PWN, 1: $24-41$.

Ga utheret R. J., 1942, Manuel technigue de culture de tissus vegetaux, Paris, Masson.

H e c ker E., 1968, Substancje czynne sprzyjające rozwojowi guzów z Euphorbiaceae, Dtsch. Spoth. Ztg. 108, 25: 872.

Howell R., Skoog F., 1955, Effect of adenine and other substances on growth of exeised Pisum epicotyls cultured in vitro, Amer. Bot. 42 (4): $356-360$, wg Ref. Żurn. 1956, 3, 9778.

K użd owicz A., 1954, Szczepienie wzajemne pomidora (Lycopersicum esculentum) i pieprzu tureckiego (Capsicum annuum), Acta Agrobotanica 2(1): 97-102.

L a n g e r on M., 1949, Precis de Mikroskopie, Paris.

Michniewicz M., 1956, Wplyw syntetycznych substancji wzrostowych na zrastanie się szczepionych roślin zielnych różnej przynależności systematycznej Cz. I, Acta Agrobotanica 4: $87-120$. 
M ontant Ch. 1957, Essais de culture in vitro de fragments de tige d'Euphorbia characies L., Compt. rend Soc. biol, 151(2): $391-392$.

Olszewska M. J., M a ciejewska-Potapczykowa W., Sempińska E. 1957, Działanie kinetyny wyizolowanej z kwasu dezoksyrybonukleinowego (z grasicy) na tkanki roślinne. II Badania anatomiczne, Acta. Soc. Bot. Pol. 26(3): $533-586$.

Rennert A,. 1965, Wzrost i hodowla in vitro tkanek z lodygi normalnej oraz tumora bakteryjnego Nicotiana tabacum L. i Crotolaria spectabilis L., Z. N. Un. Lódzkiego N. Mat. Przyr. Ser. II, 18: 135-145.

R o dkiewicz B., 1952, Obserwacje nad zrastaniem się tkanek korzenia marchwi, hodowanych in vitro, Acta Soc. Bot. Pol. 21(4): $789-801$.

R o gozińska J., 1961, Crganogeneza w tkance korzenia cykorii w zależności od obecności sacharozy i azotu w pożywce, Acta. Soc. Bot. Pol. 30, 1: 149-162.

Rogozińska J. H., 1968, Wpływ substancji wzrostowych na organogenezę pędów igliczni, Acta Soc. Bot. Pol. 37(3): 484-491.

Ruge U., 1955, Praktikum po Fizjologii Rosta i Razwitia Rastienii Izd. Inastr. Lit. Moskwa.

Skoog F., Miller C. O., 1957, Chemical regulation of growth and organ formation in plant tissues cultured in vitro, Sympos. Soc. Expt1. Biol. Vo 11 The biological action of growth substances: 118-131, cyt za Butenko 1964.

Skoog F., Hamzi Q., Hamzi and Szweykowska A. M., and Nelson J. L., Kermit L., Carraway, TozoFujii, Helgeson J. P., and Loepphy R. N.; 1967, Cytokinins: Structure/activity relationships, Phytochemistry. 6(9): $1169-1192$.

S 1 a bęck a-S z we y k o w sk a A., 1952, Warunki tworzenia się antocyjanu w tkance Vitis vinifera hodowanej in vitro., Acta Soc. Bot. Pol. 21(4): 537-576.

Szwe y k owska A., 1961, Z zagadnień morfogenezy u roślin. Nowsze wyniki badań metodą hodowli in vitro, Wiad. Bot., 5(4): $271 \longrightarrow 280$.

Torrey J. G., 1958, Endogenous bud and root formation by isolated roots of Convolvulus grown in vitro, Plant. Physiol. 33(4): 258-263.

Wetmore R. H., Serokin S., 1955, On the differentation of ksylem, J. Arnold arboretum v. 36: $305-317$.

Wojciechowska B., 1971, O zdolnościach regeneracyjnych rącznika, Acta Agrobot. 24 (w druku). 